\title{
Behavioral Insights as a New Generation of Public Service Delivery
}

\begin{abstract}
For many years behavioral insights has been on the top of political agenda. The aim of this article it to examine how the most innovative countries use this public management tool into public administration realm. In pursuit of this, behavioral insights units have been research in six countries. In conclusion author figure out that there is still a huge room for development and looking a new strategy to implement nudging in a larger scale.
\end{abstract}

Keywords: public service delivery, behavioral insights, nudge, innovation in public administration

\section{Introduction}

Searching a new way of public service delivery has been a dominant issue during last decade in public management debate. There are several reasons why it has been going like this. The most important one is the financial crisis which begun in 2008 as a result of which national governments had to face strong financial burdens. Moreover, all adherents of New Public Management finally agreed that it is not the only and the best way to manage public sector. As D. Sześciło said, a nail in the coffin for the new public management as a universal concept of the functioning of the state was the global economic crisis of recent years, the sources of which are attributed to the pathologies of the market deprived of an effective and smart regulation from the state (Sześciło, 2015). There was no better proof that market is not the only and the best regulator of public service delivery. However, there is no doubt that NPM leaves some positive impact on public sector management. Such concepts as effectiveness of public service delivery, quality management, public procurements or strategic thinking will stay in public management debate much longer than NPM. Financial problems in public sector and query of binding paradigm were a fertile ground for the emergence of new approaches. We can distinguish few crucial foundations which were common for all of them. Firstly, new services should be financed by mixed resources, both public and private, in 
order to save some public money as well as embrace citizens' involvement in public services. Secondly, a primary assumption based on economical rational theory and in consequence common belief that citizens make decision taking into consideration rational arguments remain strongly criticized. It is said that daily habits, believes and emotions drive people during their decision-making process. Last but not least, typical administration tools used to manage public issues such as control and commend have to be widened for a different course of action. It is almost impossible to introduce real change in public policy by using such awkward tools and methods of working. One of the very popular way of delivering public services which is based on assumptions mentioned above is co-production of public services. It is characterized as a long-term relation, in which each party engages its resources to improve or create a public service altogether. In this approach, there is an element of a continuum rather than a mere incidental and often one-off engagement (PodógniakKrzykacz, 2015). Thus, the co-production of public services cannot be understood only as a process of participation which is based on the exchange of information and the submission of ideas (Loeffler \& Bovaird, 2016). Hence, the co-production is a tool of public management that fundamentally transforms and reorganizes the relation between a citizen and public administration which changes the way such concepts as responsibility for the tasks performed, transparency and quality of services are understood (Meijer, 2016). Going forward, it can be said that in terms of co-production, public services are not only involving public administration activity selected by means of political choices, but are an element of interaction, co-operation and co-creation of services organized by a network of subjects representing various sectors of activity (Virtanen \& Stenvall, 2014). It might be said that this way of managing public services has still a huge room for increasing (Gawlowski, 2018).

\section{Behavioral Insight as a New Way of Public Service Delivery}

Imagine that one day you receive a letter from the town council according to which you learn that you are the only person who do not pay council tax in your street. How do you feel? Anxious, ashamed or maybe embarrassed? Probably, it will not take long until you pay your bill. Let us stop for a second and think how would traditional public administration react in this situation. It is very likely that first you will receive a warning letter. After a while, if it not succeeded, you will receive last call for payment. Everything lasts very long and consumes a lot of time and public money. This is in a nutshell the way how behavioral insights work in practice and it sounds easy and very effective.

The popularity of this course of action is based on one of the key megatrends in contemporary governance which has been the enthusiastic embrace of behavioral economics. Scientific foundation for this concept was primarily laid by Kahmenman, whose book Thinking fast and slow gave him in 2002 the Nobel Prize in economics. Kahnenman shows that our decisions are led rather by emotional factors than rational choice in almost every area of activity. Therefore, he believes that rational choice model might be used only as some 
kind of proxy. In response, he prepared theoretical proposition of dual system theory which are based of two independent parts. The first one (System 1) is dependent on automatic and abrupt decisions which very often are made unconsciously and are based on heuristics as a major factor when we decide. The second one (System 2) is much more complicated due to the fact that it is responsible for slow and conscious decisions, therefore we can say that decision-making in this system is based more on critical assumptions. To make things more important next scholars have followed his way. Thaler \& Suntein for the book Nudge, which was published in 2008, won the next Noble Prize. As they noticed, small and apparently insignificant details can have major impacts on people's behavior in almost each decision being made (Thaler\&Sustein, 2009). Therefore, the way how we design the room of decision-making process is crucial when it comes to the final results. In practice, the order of meal which pupils see in the school's kitchen exert influence on their consumption decisions; the way how people are informed about public services have a huge impact on their behavior. As Thaler \& Sustein mentioned, all of these circumstances create choice architecture which is a fertile ground for our fast thinking or System 1 as Kehneman called it. This is the way the authors coin a term 'nudge" as a concept which is based on assumption that we can enormously increase public intervention by building a system of tiny but very influential stimulus which make the differences. These are only two most important facts which open the proliferation of behavioral science and as a result was a great inspiration for further research. As Gopalan and Pirog pointed out, it starts a fascination on behavioral science not only in economic but also in different fields such as designing public policies. However, behavioral insight has some points to criticize. Some critics contend that such an overreliance on low-cost interventions has distracted governments form implementing more ambitious policies that rely on traditional policy instruments. They argue that while traditional policy instruments such as taxes and/ or subsidies might be costlier to implement and harder to receive bipartisan support, taxes and subsidies may have a much larger potential to change behavior. Nonetheless to say that there are a lot of ethical points which have to be considered during implementation process. Using the tools mentioned above has to be free of any kind of manipulation of citizens.

The way of thinking mentioned above is completely different from rational choice theory which is known in economy as a homo economicus. The main assumption is that the main factor of human behavior is based on cost and benefit analysis in almost all actions. Keeping that in mind people are constantly weighing pros and cons and deciding about their future actions according to the final result of the calculation. As we know, this theoretical assumption is divorced with practice. People often do not act when it is clearly in their interests to do so. In economic theory, behavior should be the consequence of a balance of costs and benefits, so that actions that are harmful should be considered and then individuals do something about it. The best examples which show the problem with implementation this theoretical concept are health and environmental issues. At the end of the day, despite information on actions taking place, nothing has changed. This discrepancy between theory and practice 
were noticed by Simson who called it bounded rationality and figured out that due to the lack of time and peoples' comfort only in small number of actions people are weighing the cost and benefits. Therefore, he pointed out that there is a huge room for improvement theoretical concept of rational choice theory (Simon, 1997).

The easiest way to define behavioral insight is to say that it is a non-regulatory approach that attempts to motivate individual behavior change through subtle alterations in the choice environments that people face (Olivier, 2015). Moreover, it is believed that this policy field is often called nudge which is often thought to be the idea that low-cost small changes, attuned to human psychology, can make large improvements to public policies, largely form encouraging citizens to do things that they would upon reasonable reflection agree with (John, 2018a). No longer have command and control as well as other informative action been considered as an effective public intervention. Changing peoples' behavior needs much more sophisticated actions than the previous ones. Behavior comes about from mental processes in which behavioral intentions are important. Such intensions come from an underlying set of attitudes based on beliefs and peoples' evaluation of likely outcomes. Affecting behavior is peoples' subjective norm, linked to their normative believes and motivation to comply; also, important is their perceived sense of control, which is affected by their efficacy or the belief that they can change matters for themselves (John, 2018b). So far, public administration works on completely different approach. Governments possess processing capacities that go far beyond those of individuals. These superior resources involve finance, knowledge, organization and authority. In addition, governments are, within limits, able to constrain their behavior through the generation of procedural safeguards and the establishment of particular organizations (Lodge and Wedrich, 2016). The core essence of this approach is that behavioral economics insights can be used to change the 'choice architecture' so that people are more likely to make voluntary decisions that, on reflection, they would like to make, and yet, due to bounds on their rationality and human error, ordinarily fail to do so (Oliver, 2015). Therefore, behavioral insights are defined or even created by the behavioral paradigm as a way to incorporate findings form behavioral sciences - such as social and cognitive psychology and behavioral economics-into public policy. The key point is whether there are automatic processes that govern human behavior that do not have their origins in cost-benefit thinking but derive from personal psychology. This means that human behavior can be shaped by a set of external stimuli and prompts that are not about conveying the costs and benefits of decisions, but may relate to mood, emotions, intuitions, and senses of well-being in ways that are immediately responsive and not reflected upon (John). This course of action is important to precisely understand basic principles of human behavior and the way how they make decisions. Only on this basis public interventions may be prepared precisely and effectively and as a result exert influence on people behavior. The old way of thinking in public management, which has still been implementing in public sector, based on 'carrot and stick' method have a limited effect in practice. Therefore, the better public administration understands peoples' way of thinking, the more effectively it 
may solve social and environmental problems (Sharif,2013). This is why Lodge and Wegrich pointed out that nudge does not seek to reduce irrationality in government decision making through procedures. Instead, it seeks to reduce irrationality by exploiting irrationality at the level of the target of public policy, the individual, by either harnessing unconscious biases or by encouraging individuals to be more reflective in their choices (Lodge and Wedrich, 2016).

All scientific findings mentioned above have been a great inspiration for many scholars and politicians who found out that important lessons could be drawn from this research. Therefore, some actions on international level have been taken to better understand and check possible usability of nudge in public policy. Nonetheless, first publication regarding nudging were publish by European Commission in 2016; United Nation in 2016; OECD in 2015 as well as World Bank in 2015. In this respect, United Nation has conducted research project about possible outcomes of behavioral science into policy interventions. This is the way we can find in official reports the statement that Research in behavioral science - regarding how people make decisions and act on them, how they think about, influence, and relate one to another, and how they develop beliefs and attitudes - can inform optimal programme design and make this tool important for implementing UN Agenda 2030. Moreover, the World Bank has launched Global Insights Initiative which has established a team charged with incorporating behavioral insights into organization programming. Therefore, its annual World Development Report from 2015 - entitled "Mind, Society, and Behavior" - was dedicated to a discussion on the compelling examples of behavioral science at work, reinforcing how the field can successfully address development challenges, such as breaking the cycle of poverty, boosting employment, and increasing immunization rates among children. The next step was to appoint Behavioral Science Advisor to the United Nations as a leading person in the whole organization responsible for conducting discussion about it and promote best practice. Positive response was so great that consequently the Secretary-General has launched a small team of behavioral science experts - UN Behavioral Initiative (UNBI) - charged with translating behavioral science insights into more effective and efficient UN programming and operations.

Another example of very similar action is OECD's involvement in collecting practical implementations of behavioral insight interventions through member countries and disseminating them through international audience. In pursuit of it, some public seminars and conferences were organized and a special report devoted this issue was published (OECD, 2015). In this context, behavioral insight is defined as an innovation in public service delivery which can be successfully implemented on both national and local level. According to data gathered by OECD we can distinguish some key messages for behavioral insight practitioners such as: trust as a key prerequisite; importance of culture of relation between public administration and citizens; exchanging experience between public and private sector where some experiments are conducted from time to time. 


\section{Methodology}

The aim of the article is to find out what role behavioral insights play in public interventions in the most innovative countries. The research hypothesis is that behavioral insight is not a temporary trend in public management but a new paradigm in public service delivery which develops in public administration realm. To make falsification of this assumption few questions were raised: (1) What kind of organizational arrangement have been implemented to develop behavioral insights interventions?; (2) What kind of organizational and financial resources have been devoted to behavioral insight actions?; (3) Is there any tangible effect of behavioral insight projects which exert an influence on public administration practice? In order to answer these questions and as a result make a falsification of research hypothesis few countries were chosen including United Kingdom, Denmark, Sweden, Australia, Canada and USA. The reason why these particular countries are studied is that it is believed that they have the most innovative public administration organizations in the world. The most important sources of information which help to conduct research are official documents and development strategies of public administration; searching special administration units devoting behavioral insights in each country; and last but not least learning some tangible effects according to summary reports prepared by these units.

\section{Results}

The first country in which behavioral insights were considered seriously was the United Kingdom. It was 2010 when the first unit was launched and it was situated directly in 10 Downing Street in the Communication and Strategy Unit. Given the growing interest at innovation in public services, The Behavioral Insight Team was located in The Cabinet Office and strengthened both organizationally and financially. However, it is not the end of the structural development due to further evolution. In February 2014 Behavioral Insights Team changed to mutual joint venture which were created with Nesta - charity think tank mostly focused on public sector innovations. Nowadays, BIT (sometimes called Nudge Unit) has expanded to New York, Manchester, Singapore, Sydney, Wellington. Last published report which presents summary of 2016-2017 realizes information about 163 trials which were conducted in 25 countries. All of these actions were made in such areas as: health and welfare; crime, security and integration; customers and finance; economic growth and productivity; energy and suitability; community and giving; local government and cities; international programmes.

The British experience was a huge inspiration for the US government. Therefore, in February 2014 President Barrack Obama started the Social and Behavioral Science Team (SBST) which was a part of the White House Office of Science and Technology Policy in order to reach greater flexibility in public services, increase their effectiveness and do more for spending less. After first year of SBST running, President B. Obama issued an 
executive order directing Federal Government agencies to apply behavioral science insights to their programs to better serve the American people and consequently increase federal spending for SBST trial research. During the first year of action the SBST was focusing on projects in two areas where behavioral science had a strong role to play and impacts could be demonstrated relatively rapidly: (1) streamlining access to programs and (2) improving government efficiency (SBST Report, 2015). During the next year SBST's work tracks three major themes: (1) ensuring access to affordable health insurance for the millions of Americans who still lack coverage, expanding economic opportunity for workers and their families, and reducing U.S. greenhouse gas emissions; (2) leveraging an ever broader set of strategies to maximize impact, from changing how programs communicate with individuals, to modifying the way programs are administered, to informing the design of policy; (3) drawing on the best available evidence and rigorously testing the impact of its projects to inform recommendations about what to scale and what to improve (SBST Report, 2016). This growing scope of interest of SBST was finally finished by getting the group into abeyance in January 2017.

Canada can be presented as another country in which a government decided to launch Behavioral Insights Unit (BIU). It happened in 2015 as a part of the Centre of Excellence for Evidence-Based Decision Making within the Treasury Board Secretariat. The aim of BIU is to support the application of a behavioral science lens in policy development and programme implementation. From the beginning the main idea of this kind of unit is to work collaboratively with numerous ministries, agencies and other levels of government in order to successfully disseminate knowledge and experience about nudging. Therefore, BIU provides advisory services and attracts potential partners to join to this network. At the beginning, first course of action was focused on back-office procedures in public administration such as the shape of registration forms. However, the next steps were linked with different policy realms such as recycling behavior, employer health tax or vaccination reporting for children. As we can find out in the governmental report summarizing BIU achievements, there is a growing awareness that it is still a very young unit, but it has already begun changing not just the way a government designs policies, but the way a government thinks about designing policies. The BIU recognizes, however, that there is not only a great deal left to do, there is also a great deal left to learn (Ontario's BIU, 2018) which means that we can expect further development in near future.

In 2012 Behavioral Insights Unit was created also by the Government in Australia as one of departments in Premier and Cabinet Office. The main task is to improve effectiveness of public services and policy in such areas as: domestic violence, childhood obesity and criminal reoffending. During next years, the scope of goal was gradually increasing and nowadays the list consists such tasks as: running major trials, providing policy advice and supporting government agencies that are running their own behavioral trials and interventions; building the capability of the public sector to apply BI through training, resources, and hosting events with leading thinkers and practitioners; contributing to the global body 
of BI evidence by collaborating with academia and publishing trial results. Even though the Unit has existed for more than 6 years, it is hard to show tangible effects which truly change public service delivery.

Some actions towards implementing behavioral insights can be seen in Sweden. Compering to previously mentioned country, the Swedish government has not launched any governmental unit focusing on this issue. However, the concept of nudging is well known among relevant actors, to the extent that the Swedish Environmental Agency published in 2014 a report entitled "Nudging - A tool for sustainable behavior" in which the author describes potential avenues for employing behavioral science in policy making and suggests institutionalization paths to ensure this. The report shows how environmental issues can be mitigated through nudging. Moreover, some municipalities have conducted experiments in order to implement nudging tools into public services. The way how behavioral insights are developing in Sweden is co-financing external partner actions such as the Swedish Nudging Network (SNN) and Nudge Sweden (NS) which are existing at Swedish national level. The SNN is a network of organizations, institutions and companies which try to develop nudging tools into their practice. In order to exchange knowledge and best practice, SNN became a member of the European Nudge Network and in this way works on the international level. NS works on voluntary basis likewise SNN. However, it is mainly focused on public services, therefore some members come from the public sector.

Not only Sweden but also Denmark does not have any governmental unit regarding nudging. As a result, we can distinguish some bottom-up initiatives such as Danish Business Authority, local governments teams which are launching on voluntary basis as well as special research group at the Roskilde University. However, what is worth mentioning, civil servants have been trained on this occasion in order increase their awareness of this kind of actions. One of the most fruitful initiatives regarding nudging is Copenhagen Behavioral Economics Network which was created to increase knowledge sharing, following the successful example of the London Behavioral Economics Network

Tab 1. Behavioral Insights Units among Different Countries

\begin{tabular}{lllll}
\hline $\begin{array}{l}\text { Issue } \\
\text { Country }\end{array}$ & $\begin{array}{l}\text { Date of establish- } \\
\text { ment }\end{array}$ & $\begin{array}{l}\text { Place in public } \\
\text { administration }\end{array}$ & $\begin{array}{l}\text { Organizational } \\
\text { assets }\end{array}$ & Tangible effects \\
\hline $\begin{array}{l}\text { United King- } \\
\text { dom }\end{array}$ & $\begin{array}{l}\text { 2010- Behavioral } \\
\text { Insights Unit }\end{array}$ & $\begin{array}{l}\text { Primarily 10 Down- } \\
\text { ing Street/ Cabinet } \\
\text { Office; actually joins } \\
\text { venture with Nesta }\end{array}$ & $\begin{array}{l}\text { 142 people working } \\
\text { in locations }\end{array}$ & $\begin{array}{l}\text { Leading nudging } \\
\text { international com- } \\
\text { munity; changes in } \\
\text { almost 20 public }\end{array}$ \\
& & & Services \\
\hline USA & $\begin{array}{l}\text { 2014- Social and } \\
\text { Behavioral Science } \\
\text { Team }\end{array}$ & $\begin{array}{l}\text { White House Office } \\
\text { of Science and } \\
\text { Technology Policy }\end{array}$ & $\begin{array}{l}\text { During the SBST } \\
\text { running - 9 people }\end{array}$ & $\begin{array}{l}\text { Executive order } \\
\text { directing Federal } \\
\text { Government agen- } \\
\text { cies to apply behav- } \\
\text { ioral science insights } \\
\text { to their programs }\end{array}$ \\
\hline
\end{tabular}




\begin{tabular}{|c|c|c|c|c|}
\hline $\begin{array}{l}\text { Issue } \\
\text { Country }\end{array}$ & $\begin{array}{l}\text { Date of establish- } \\
\text { ment }\end{array}$ & $\begin{array}{l}\text { Place in public } \\
\text { administration }\end{array}$ & $\begin{array}{l}\text { Organizational } \\
\text { assets }\end{array}$ & Tangible effects \\
\hline Canada & $\begin{array}{l}2015 \text { - Behavioral } \\
\text { Insights Unit }\end{array}$ & $\begin{array}{l}\text { Part of the Centre } \\
\text { of Excellence for } \\
\text { Evidence-Based } \\
\text { Decision Making } \\
\text { within the Treasury } \\
\text { Board Secretariat }\end{array}$ & 5 people & $\begin{array}{l}\text { Changes in } 5 \text { public } \\
\text { services }\end{array}$ \\
\hline Australia & $\begin{array}{l}2012 \text { - Behavioral } \\
\text { Insights Unit }\end{array}$ & $\begin{array}{l}\text { One of Department } \\
\text { in Premier and } \\
\text { Cabinet Office }\end{array}$ & 13 people & $\begin{array}{l}\text { Changes in almost } \\
10 \text { public services }\end{array}$ \\
\hline Denmark & None & $\begin{array}{l}\text { Developing } \\
\text { networks among } \\
\text { different kind of } \\
\text { partners }\end{array}$ & None & None \\
\hline Sweden & None & $\begin{array}{l}\text { Developing } \\
\text { networks with the } \\
\text { Swedish Nudging } \\
\text { Network and Nudge } \\
\text { Sweden }\end{array}$ & None & $\begin{array}{l}\text { Report of the Swed- } \\
\text { ish Environmental } \\
\text { Agency published } \\
\text { in } 2014\end{array}$ \\
\hline
\end{tabular}

Source: Own studies.

\section{Discussion}

For the last years, nudging has come on the top of reform agenda in many countries and international organizations. After 2008, when "Nudge" was published, a growing number of countries introduced certain course of actions in order to achieve more flexible and effective public services. One of the reasons why there is a growing interest in this issue is its huge promotion by international organizations such as European Union, World Bank or OECD. From my perspective, there are several reasons on this fact. The first one is quick facility to implement nudging tools into public administration practice which is neither complicated, nor time-consuming. Moreover, it is unnecessary to draft any legal amendments or introduce huge institutional reforms. Considering the fact that subtly changes may bring abrupt change is the best encouragement to start the process. The second reason is strictly linked with financial resources which have to be engaged. Rarely do innovations in public administration require so little expenditures in their implementation, therefore many countries ought to be more eager to go this path. Moreover, nudging implementation very often brings more revenue for local budget in short and long-term, therefore it is hard to resist the temptation to try on this tool of public management. Last but not least, it is hard to indicate any opponents of this course of action, as it is very often in previous innovation tools. Therefore, it is easy to build coalition composed with civil society partners, academia and private sector.

It seems to be certain that nudging will remain in public administration realm for a long time. All researched countries have had some experiences in this way of public management. 
Moreover, four countries out of six have established special units' clause to cabinet office in order to conduct research and trials. This is the best proof that nudging has a priority or high position in public administration. The remaining two studied countries made some actions to strengthen civil servants' awareness to this issue and/ or to build network with other organizations on both local and national level.

When it comes to tangible results, few conclusions might be drawn. The first one is that nudging is becoming one of the assessment parts of legislative process. The best example are both the European Commission and the US legislative processes. It means that each of drafted acts will have to be mandatory scrutinized in the nudge way of thinking, however, we still have to wait for any further conclusions. The second thing is that during last year's there can be shown a huge number of small changes which have been introduced and made positive results on public service delivery. It is still too less to say that nudging has deeply reshaped public administration, however, it cannot expel the fact that we are witnessing ripple effect on the world wide scale.

The intriguing fact is that in almost each behavioral insight unit there are only a handful of people who work there. Probably, it is the best fact which should attract politicians to launch such units in their governmental administration. The only exception is the Behavioral Insights Team in the UK in which more than 130 people work. However, it is important to remember that the British example is completely different from others due to the fact that BIT is operating on international level, in different countries.

For the time being we cannot say that nudging is a fertile ground for public administration revolution. There is a growing recognition of this type of public service delivery, a huge number of projects finished successfully and we can expect that in the future the next ones will be introduced. There is still a huge room for development and looking a new strategy to implement nudging to a larger scale. Nowadays, each country deals with it by working on each public service separately and as a result it makes it a very tedious strategy. However, we have to remember that each successful implementation causes positive impact on public health, protecting environment, safety and social integration or any other public realm.

\section{References}

Bovaird, T., Loffler, E. (ed.). (2015). Public Management and Governance. New York: Routhledge. European Union. (2016). Behavioral Insights Applied to Policy. European Report 2016. Brussels. Gawlowski, R. (2018). Co-Production of Public Services in Terms of Polish Experiences. Polish Political Science Yearbook, vol. 47, Issue 1, pp. 110-120.

Haber, A., Olejniczak, K. (2014). (R)ewolucja 2. Wiedza w działaniu. Warsaw: Polska Agencja Rozwoju Przedsiębiorczości.

Hagman, W. et al. (2015). Public Views on Policies Involving Nudges. Review of philosophy and psychology, Vol. 6, No. 3.

John, P. (2016). Experimentation, Behavior Change and Public Policy. The Political Quarterly, vol. 84, No. 2. 
John, P. (2018). How Far to Nudge? Assessing Behavioral Public Policy. Northampton: Edward Elgar Publishing.

Kahneman, D. (2013). Thinking fast and slow. New York: Farrar, Straus and Giroux.

Meijer, A. (2016). Co-production as a structural transformation of the public sector. International Journal of Public Sector Management, vol. 29, No. 6.

Lodge, M. and Wegrich, K. (2016). The Rationality Paradox of Nudge: Rational Tools of Government in a World of Bounded Rationality. Law\&Policy, Universtiy of Denver, vol. 38, No. 3.

Mont, O., Lehner, M. and Heiskanen, E. (2014). Nudging. A tool for sustainable behavior?. Stockholm: Swedish Environmental Agency.

OECD. (2015). Behavioral insights and the new approaches to policy design. The fields from the field. Paris.

Oliver, A. (2015). From Nudging to Budging: Using Behavioral Economics to Inform Public Sector Policy. Journal of Social Policy, vol. 42, Issue 4.

Pelenur, M., and Reinhard, J. (2014). EAST: Four simple ways to apply behavioral insights. U.K. Cabinet Office and Nesta.

Podgórniak-Krzykacz,A. (2015). Co-production for local public services - a case study of the cooperative Hallenbad Norten-Hardenbert. Zarządzanie Publiczne. No. 2(30).

SBST. (2015). Social and Behavioral Science Team. Annual Report 2015. Washington.

SBST (2016). Social and Behavioral Science Team. Annual Report 2016. Washington.

Sharif, E. (2013). The Behavioral Foundations of Public Policy. Princeton: Princeton University Press.

Simon, H.A. (1997). Administrative Behavior, Edition. New York: Free Press.

Sunstein, C. and Thaler, R. (2008). Nudge. Yale University Press.

Sześciło, D. (2015). Współzarządzanie jako koprodukcja usług publicznych. Zarządzanie Publiczne, No. $1(31)$.

Room, G. (2016). Nudge or nuzzle? Improving decisions about active citizenship. Policy studies, vol. 37, No. 2.

Thaler, R.H., Sustein, C.R. (2009), Nudge: Improving Decision about Health, Wealth, and Happiness. London: Penguin Books.

The Behavioral Insights Team in UK. (2017). The BIT Update Report 2016-2017. London.

The Behavioral Insights Unit in Ontario. (2018). The Behavioral Insight Unit Update Report 2018. Ontario.

The Behavioral Insights Unit in Australia. (2018). The Behavioral Insight Unit Report 2018. Wellington. United Nations (2013). Behavioral Insights at the United Nations. Achieving Agenda 2030. New York. Virtanen, P., Stenvall, J. (2014). The evolution of public services from co-production to co-creation and beyond. The International Journal of Leadership in Public Service, vol. 10, No. 2.

\section{Author}

\section{Robert Gawłowski}

robert.gawlowski@wsb.bydgoszcz.pl - WSB University in Toruń, Faculty of Finance and Management Department in Bydgoszcz; contact details: ul. Młodzieżowa 31a, 87-100 Toruń, Poland. 